\title{
Urgences
}

\section{Paysage artificiel}

\section{Ginette Perron-Chouinard}

Numéro 1, 2e trimestre 1981

URI : https://id.erudit.org/iderudit/025014ar

DOI : https://doi.org/10.7202/025014ar

Aller au sommaire du numéro

Éditeur(s)

Urgences

ISSN

0226-9554 (imprimé)

1927-3924 (numérique)

Découvrir la revue

Citer ce document

Perron-Chouinard, G. (1981). Paysage artificiel. Urgences, (1), 78-82.

https://doi.org/10.7202/025014ar

Ce document est protégé par la loi sur le droit d'auteur. L'utilisation des services d'Érudit (y compris la reproduction) est assujettie à sa politique d'utilisation que vous pouvez consulter en ligne.

https://apropos.erudit.org/fr/usagers/politique-dutilisation/
Cet article est diffusé et préservé par Érudit.

Érudit est un consortium interuniversitaire sans but lucratif composé de l'Université de Montréal, l'Université Laval et l'Université du Québec à Montréal. Il a pour mission la promotion et la valorisation de la recherche. https://www.erudit.org/fr/ 
Ginette Perron-Chouinard 
Tant de douceur sécrétée par ton visage Les larves immortelles iront éclater dans les champs de blé qui boivent le sang des pluies fécondées par le soleil de ton pays

Mon visage tremblait comme feuille sur l'eau Il s'est allongé comme une flaque d'os Mon visage a craqué Il est tombé en glaçons d'argile dans le creux lové de tes mains

Tu as voulu le façonner mais la glaise s'infiltrait entre tes doigts et c'est mon visage qui a façonné tes mains

Tes mains sont devenues mes cheveux Elles formaient couronne sur ma tête Je les ai avalées Elles sont devenues mes bronches et mes artères mon sourire et mes lèvres ta bouche et mon visage le soleil et mon corps

La nuit folle d'étoiles riait

avec des gloussements de vent J'ai entendu l'aurore paître des troupeaux de lumière 


\author{
J'ai entendu ton cri \\ briser les barrières du sang \\ Il tombait goutte à goutte \\ sur le cuivre givré de mon bras \\ Il a fait un trou \\ dans la chair molle \\ où la nuit a fait son lit
}




\section{LA CHIMOUERE}

Le ciel $m$ 'affuble de ce soir d'espoir

J'ai mis ma grande chasuble de neige froide et je vole dans le ciel noir comme une grande mouette seule Tourne et voltige belle mouette dans tes sortilèges Ton amant vogue sur le fleuve de la déraison et te tient entre ses mains comme une chimère

Je suis une chimouère en cibouère de ne pouvoir m'accoupler à ton corps volant sur l'eau gelée emprisonnée

Pourtant les mouettes ne sont pas des chimères Mais moi je suis une chimouère

Non ne danse pas ne tourne pas ni ne voltige

Non te rappelles-tu magnifique bateau tu me disais Reste dans ton armoère fatiguée comme un balai de sa journée sa rondeur prenant les plis des encoignures sa tête blonde en bas raide et figée comme celle d'un yogi voulant raviver son sang 
Non ne danse pas

ne tourne pas ni ne voltige

Reste calme chimouère

Reste mouette par terre

sans chimère en l'air

Les bateaux peuvent vaincre les tempêtes

mais pas les fragiles oiseaux

Reste

Je remonte le courant froid du fleuve

et mes bras de bois gaspésien

vont rejoindre tes bras de porcelaine

de plumes mouillées et de chimères dorées

Et la chimouère rase le sol

en tournant et soulevant

de grandes gerbes de neige

Et elle sent le vent qui gonfle ses ailes

Et elle se bat pour rester au sol

pour être là quand le beau bateau arrivera

Et alors la chimouère se juchera

sur son grand mât

Et la chimère s'envolera

en Chine ou en mer

et laissera la mouette

tête blonde et ailes de porcelaine

défiant tous les vents

au creux des bras de laine

de son amant gaspésien 